

\section{DISCLAIMER}

This report was prepared as an account of work sponsored by an agency of the United States Government. Neither the United States Government nor any agency Thereof, nor any of their employees, makes any warranty, express or implied, or assumes any legal liability or responsibility for the accuracy, completeness, or usefulness of any information, apparatus, product, or process disclosed, or represents that its use would not infringe privately owned rights. Reference herein to any specific commercial product, process, or service by trade name, trademark, manufacturer, or otherwise does not necessarily constitute or imply its endorsement, recommendation, or favoring by the United States Government or any agency thereof. The views and opinions of authors expressed herein do not necessarily state or reflect those of the United States Government or any agency thereof. 


\section{DISCLAIMER}

Portions of this document may be illegible in electronic image products. Images are produced from the best available original document. 
Printed in the United States of America Available from

Clearinghouse for Federal Scientific and Technical Information National Bureau of Standards, U. S. Department of Commerce Springfield, Virginia 22151

Price: Printed Copy $\$ 3.00$; Microfiche $\$ 0.65$

\section{LEGAL NOTICE}

This report was prepared as an account of Government sponsored work. Neither the United States, nor the Commission, nor any person acting on behalf of the Commission:

A. Makes any warranty or representation, express or implied, with respect to the accuracy, completeness, or usefulness of the information contained in this report, or that the use of any information, apparatus, metliul, or process disclosed in this report may not infringe privately owned rights; or

B. Assumes any liabilities with respect to the use of, or for damages resulting from the use of any information, apparatus, method, or process disclosed in this report.

As used in the above, "person acting on behalf of the Commission" includes any employee or contractor of the Commission, or employee of such contractor, to the extent that such employee or contractor of the Commission, or employee of such contractor prepares, disseminates, or provides access to, any information pursuant to his employment or contract with the Commission, or his employment with such contractor. 
IN- 1178

Issued: April 1968

Chemistry

TID-4500

\title{
BURNUP DETERMINATION
}

OF NUCLEAR FUELS

PROJECT REPORT

FOR THE QUARTER APRIL 1 - JUNE 30, 1967

Edited by

Frederick L. Lisman, William J. Maeck, and James E. Rein

\begin{abstract}
ए
LEGAL NOTICE

This report was prepared as an account of Government sponsored work. Netther the United States, nor the Commission, nor any person acting on behalf of the Commisslon:

A. Makes any warranty or representation, expressed or implied, with respect to the accuracy, completeness, or usefulness of the information contained in this report, or that the use of any information, apparatus, method, of prucess diselosed in this report may not Infringe privately ownod rights:

pritely owned rght; or

B. Assumes any liabilities with respect to the use of, or for damages resulting from the use of any information, apparatus, method, or process disclosed in this report.

As used in the above. "person acting on behalf of the Commission" includes any employee or contractor of the Commission, or employee of such contractor, to the extent that such employee or contractor of the Commission, or employee of euch contractor prepares, disseminates, or provides access to, any Informatlon pursuant to his employment or contract with the Commission, or his employment with such contractor.
\end{abstract}

\section{IDAHO NUCLEAR CORPORATION}

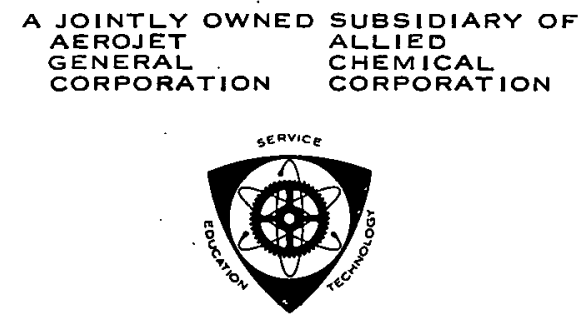

U. S. Atomic Energy Commission Research and Development Report

Issued Under Contract A T(10-1)-1230

Idaho Operations Office 
BURNUP DETERMINATION

OF NUCLEAR FUELS

'PROJECT REPORT

FOR THE QUARTER APRIL 1 - JUNE 30, 1967

Edited by

Frederick L. Lisman, William J. Maeck, and James E. Rein

\author{
Contributing Personnel \\ Analytical Development Section \\ W. A. Emel \\ R. E. Foster \\ M. E. Kussy
}

Mass Speclirometry Group

R. M, Abernathcy

L. W. Buttaris

L. L. Dickerson

R. E. McAtee

R. A. Nielsen

A. H. Toepfer

G. D. Workman

Operations Analysis (Statistics)

F. W. Spraktes 


\section{SUMMARY}

In this continuing program to develop methods for the accurate determination of the burnup of nuclear fuels; the main emphasis this quarter was additional measurements of the absolute, thermal fission yields of stable and long-lived isotopes of krypton, xenon, rubidium, and rutherium. for U-235. Also measured was $\alpha$, the thermal capture-tofission ratio, for U-235. The determined values are:

\begin{tabular}{|c|c|c|c|c|}
\hline Isotope & Fission Yield & Isotope & & Fission Yiel \\
\hline $\mathrm{Kr}-83$ & 0.529 & $R u-102$ & & $4.21 \pm 0.06$ \\
\hline $\mathrm{Kr}-84$ & 0.980 & Ru-104 & & $1.84 \pm 0.02$ \\
\hline $\mathrm{Kr}-85(10.76 \mathrm{yr})$ & 0.282 & $\mathrm{Ru}-106$ & & $0.414 \pm 0.010$ \\
\hline $\mathrm{Rb}-85$ & $1.30 \pm 0.02$ & $\mathrm{Ru}-106$ & $\begin{array}{l}\text { (radio- } \\
\text { metric) }\end{array}$ & $0.404 \pm 0.015$ \\
\hline $\mathrm{Kr}-86$ & 1.86 & $\mathrm{Xe}-131$ & & $2.72 \pm 0.06$ \\
\hline $\mathrm{Rb}-87$ & $2.52 \pm 0.03$ & $\mathrm{Xe}-132$ & & $4.04 \pm 0.09$ \\
\hline $\mathrm{Ru}-101$ & $5.05 \pm 0.07$ & $\mathrm{Xe}-134$ & & $7.34 \pm 0.17$ \\
\hline
\end{tabular}

These values are tentative and as additional capsules are analyzed, refined data will be reported. Previous project reports are:
Annual - 1962
Annual - 1963
TID-17385
Annual - 1964
IDO-14649
Quarter, January-March, 1965
IDO- 14656
Quarter, April-June, 1965
IDO- 14660
Quarter, July-September, 1965
IDO- 14663
IDO-14667
Quarter, October-December, 1965
IDO- 14676
Quarter, January-March, 1966
IDO- 14678
Quarter, April-June, 1966
IDO-14681
Quarter, July-September, 1966
IN-1064
Quarter October-December, 1966
IN -1113
Quarter, January-March, 1967
IN-I157 Rev. 


\section{THIS PAGE \\ WAS INTENTIONALLY \\ LEFT BLANK}


CONTENTS

Page

SUMMARY . . . . . . . . . . . . . . . . . i ii

INTRODUCTION . . . . . . . . . . . . . . . . . 1

ABSOLUTE U-235 THERMAL FISSION YIELDS FOR THE STABLE AND

LONG-LIVED FISSION PRODUCTS OF KRYPTON, XENON, RUBIDIUM,

AND RUTHENIUM ................... 2

IRRADIATION HISTORY OF CAPSULES . . . . . . . . 2

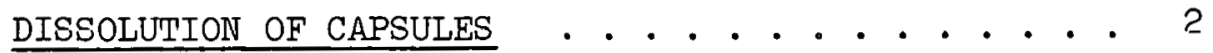

DERERMINATION OF NUMBER OF U-235 FISSIONS - . . . . 2

CAPTURE-TO-FISSION RATIO FOR U-235 . . . . . . . 6

CALCULATION OF $\hat{\alpha}$ FOR U-235 . . . . . . . . . 6

KRYPTON AND XENON FISSION YIELDS . . . . . . . . 7

$\mathrm{Rb}-85$ and $\mathrm{Rb}-87$ FISSION YIELDS . . . . . . . . 11

RUTHENIUM FISSION YIELDS....... .13

COMPARISON TO PREVIOUS RESULTS . . . . . . . . 13

REFERENCES .................. 16 


\section{TABLES}

Page

I. ANALYSIS RESULTS OF IRRADIATED U-235 CAPSULE AND CALCULATED. NUMBERS OF ATOMS . . . . . . . . 5

II. THERMAL FISSION YIELDS OF KRYPTON ISOTOPES FOR U-235 . . . . . . . . . . . . . . 9

III. THERMAL FISSION YIELDS OF XENON ISOTOPES FOR U-235 . . . . . . . . . . . 10

IV. THERMAL FISSION YIEI.DS OF Rb-85 and Rb-87 FOR U-2.3.5

V. THERMAL FISSION YIELDS OF LONG-LIVED AND STABLE RUTHENIUM ISOTOPES FOR U-235 . . . . . . 14

VI. FISSION YIELD COMPARISON . . . . . . . . . 15 


\section{BURNUP DETERMINATION OF NUCLEAR FUELS}

\section{INTRODUCTION}

The objective of this project is the development of methods for the accurate determination of burnup of nuclear fuels. The emphasis is on power reactor fuels having long residence time and high burnup rather than on short term, experimental irradiations. The principal measurement technique under study is chemical analysis for fission products. The use of long-lived, radiochemically determined fission products is not applicable because the errors of the in-pile decay corrections are magnified with long term irradiations, the nuclear constants are not known with sufficient accuracy, and the few available nuclides, Cs-137 and Sr-90, are volatile. The use of stable fission product nuclides, determined by isotope dilution mass spectrometry, has therefore been selected. The degree of reliability of a burnup determination based on stable fission product analyses depends on three factors; the accuracy of the values used for fission yields, the linearity between the number of fissions and the number of fission product atoms present at the end of the irradiation, and the reliability of the analysis methods.

Specific goals of this project are the accurate measurement of the fission yields of selected nuclides for various fissioning isotopes, the selection of fission product nuclides for use as fission. monitors for various fuel types, and the development of separation and mass analysis methods for these nuclides. Presently, experiments are in progress to measure the absolute thermal fission yields for $\mathrm{U}-233, \mathrm{U}-235, \mathrm{Pu}-239$, and Pu-241 to a high degree of accuracy. Later in the program, fast fission yields will be measured.

Initial values for many $U-233$ and $U-235$ thermal fission yields have been reported in previous reports IDO-14660, IDO-14663, IDO-14667, IDO-14676, IDO-14678, IDO-14681, IN-1064, IN-1113, and IN-1157 Rev. 


\section{ABSOLUTE U-235 THERMAL FISSION YIELDS \\ FOR THE STABLE AND LONG-LIVED FISSION \\ PRODUCTS OF KRYPTON, XENON, RUBIDIUM, AND RUTHENIUM}

The major goal of the burnup project is the accurate determination of the thermal fission yields of long-lived and stable fission products. A series of capsules containing weighed amounts of the oxides of highly enriched U-233, U-235, Pu-239, and Pu-24l was prepared and irradiated in the MTR ( 1 ). During this quarter, the last of four U-235 capsules was dissolved and the absolute fission yields were measured for isotopes of krypton, xenon, rubidium, and ruthenium. Also measured was $\alpha$, the thermal capture-to-fission ratio for $\mathrm{U}-235$.

Irradiation History of Capsule

Standard burnup capsule CPP-6-5-3, which contained $122.0 \mathrm{mg}$ of highly enriched $\mathrm{U}_{3} \mathrm{O}_{8}$ mixed with high-purity aluminum powder and welded in a high-purity aluminum tube, was irradiated for two fuel cycles ( $1290 \mathrm{Mwd})$ in the MTR at an estimated unperturhed flux of $6 \times 10^{13}$ $\mathrm{n} / \mathrm{cm}^{2}-\mathrm{sec}$ (accumulated $\mathrm{nvt}=1.7 \times 10^{20}$ ). The cadmium ratio for cobalt for this irradiation was 15. The capsule was discharged from the reactor July 20, 1964, and allowed to cool for about three years before dissolution.

Dissolution of Capsule, (R. E. Foster, Jr., W. A. Emel)

The dissolution of the capsule was carried out in a. 4-in. leadshielded facility. The dissolution apparatus has been previously described $(1,2)$. The dissolver flask and reflux condenser were fabricated from high-purity quartz and an acid mixture of $6 \mathrm{M} \mathrm{HCl}-1.6 \mathrm{M} \mathrm{HNO}_{3}$, prepared from quartz-distilled reagents, was used for the dissolution (I).

The dissolution proceeded smoothly and was complete in $3.5 \mathrm{hr}$. The fission gases, krypton and xenon, appeared $1 \mathrm{hr}$ after the start of the dissolution and their evnintinn continued for $2 \mathrm{hr}$. The firal sululiun (about $200 \mathrm{ml}$ ) was water clear and contained no residue.

After cooling, the dissolver solution was quantitatively transferred to a calibrated $250-\mathrm{ml}$, quartz volumetric flask with the aid of $6 \mathrm{M} \mathrm{HCl}-1.6 \mathrm{M} \mathrm{HNO}_{3}$ rinses. The solution was diluted to volume with quartz-distilled water, a Teflon-coated bar magnet was introduced, and the contents were stirred for $1 \mathrm{hr}$.

Determination of Number of U-235 Fissions; (R. M. Abernathey, L. W. Buttars, F. L. Lisman, R. A. Nielsen, F. W. Spraktes).

The accuracy of the absolute fission yield measurements directly depends on the accuracy of the determined number of fissions in the 
irradiated U-235 capsule. For this reason, a large effort was placed on the pre- and postirradiation analyses for the atoms of the various uranium isotopes from which the number of fissions was calculated.

The $\mathrm{U}_{3} \mathrm{O}_{8}$ (obtained from ORNL) that was weighed into the capsule was analyzed both for weight percent uranium content and isotopic distribution. For the former, samples of the $\mathrm{U}_{3} \mathrm{O}_{8}$ were weighed on a microbalance and dissolved in nitric acid, weighed aliquots were mixed with weighed aliquots of a standard U-233 solution, and the mixtures were analyzed by isotope diLution mass spectrometry. Isotopic distribution was determined on unspiked samples. The calculated atoms of each uranium isotope (in the capsule charge of $122.0 \pm 0.1 \mathrm{mg} \mathrm{U}_{3} \mathrm{O}_{8}$ ) are summarized in Table $I$. Of interest was the finding that the uranium content of the $\mathrm{U}_{3} \mathrm{O}_{8}$ corresponded to $99.62 \%$ of theoretical.

The postirradiation atoms of each uranium isotope were determined in a similar manner with unspiked and U-233 spiked aliquots of the dissolver solution. The aliquots of the dissolver solution were delivered

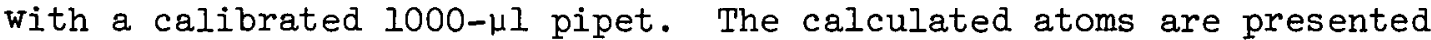
in Table $I$.

The number of U-235 fissions was calculated from the relationship:

$$
F_{5}=U^{\circ}-U
$$

in which:

$$
\begin{aligned}
& F_{5}=\text { number of } \mathrm{U}-235 \text { fissions } \\
& U^{\circ}=\text { preirradiated atoms of uranium } \\
& U=\text { total postirradiated atoms of uranium }
\end{aligned}
$$

To accurately use this relationship, one must account for those atoms of U-236 and U-238 lost by capture and subsequent decay to nonuranium isotopes. This was done with data obtained from a computer program which simulated the history of the irradiation. Discussion and details of the buildup and burnout calculations have been reported previously (2).

From the results:

$$
\begin{aligned}
& U^{\mathrm{O}}=\left(2.6355^{ \pm 0} 0.0029\right) \times 10^{20} \\
& U=(2.3649 \pm 0.0016) \times 10^{20}
\end{aligned}
$$

The number of fissions, $F_{5}=(0.2706 \pm 0.0033) \times 10^{20}$ 
The propagated standard deviation error of $0.0033 \times 10^{20}$ for the computed number of fissions corresponds to a relative error of $1.22 \%$. The atom percent U-235 fissioned (defined as atoms of U-235 fissioned per 100 initial atoms of $\mathrm{U}-235$ ) is :

$$
\begin{aligned}
\% F_{5} & =\frac{100(0.2706 \pm 0.0033) \times 10^{20}}{(2.6135 \pm 0.0029) \times 10^{20}} \\
& =10.35 \pm 0.13 .
\end{aligned}
$$

in which the value of 0.13 is the propagated standard deviation error and corresponds to a relative error of $1.22 \%$. 
Table I. ANALYSIS RESULTS OF IRRADIATED U-235 CAPSULE AND CALCULATED NUMBERS OF ATOMS

Preirradiation Data

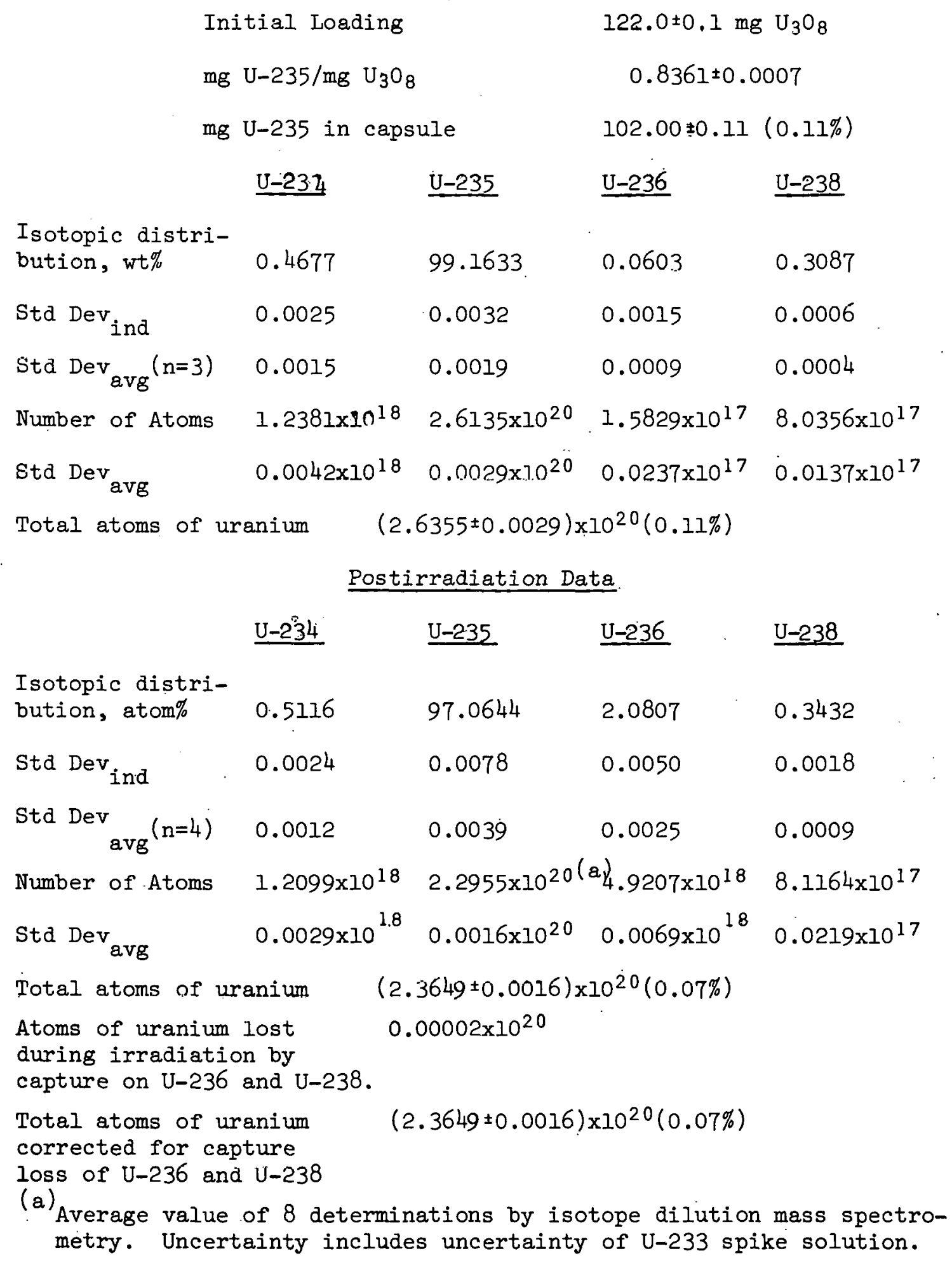


Capture-to-Fission Ratio for U-235 (F. L. Iisman, F. W. Spraktes)

The effective capture-to-fission ratio, $\hat{\alpha}$, is calculated from the data of Table $I$. The number of U-235 atoms captured to form U-236 equals the postirradiation number of U-236 atoms plus those lost by capture to U-237 (and $B^{-}$decay to $\mathrm{Np}-237$ ) less those atoms of U-236 initially present in the loading. As stated previously, the number of U-236 atoms lost by capture was calculated from a computer program.

\section{Calculation of $\hat{\alpha}$ for U-235}

(1) atoms $\mathrm{U}_{6}$ present at end of irradiation $=(4.9207 \pm 0.0069) \times 10^{18}$

(2) atoms $\mathrm{U}_{6}$ lost by capture

$=0.0077 \times 10^{18}$

(3) (1) $+(2)$

$=(4.9284 \pm 0.0069) \times 10^{18}$

(4) atoms $U_{6}^{\circ}$, initial atoms loaded

$=(0.1583 \pm 0.0024) \times 10^{18}$ into capsule

(5) atoms $U^{\circ}{ }_{5}$ captured to $U_{G},(3)-(4)$

$=(4.7701 \pm 0.0073) \times 10^{18}$

(6) atoms $\mathrm{U}^{\circ}{ }_{5}$ fissioned (see previous section) $=(27.06 \pm 0.33) \times 10^{18}$

(7) $\hat{\alpha},\left(\right.$ atoms $U^{\circ}{ }_{5}$ captured/atoms $U^{\circ}{ }^{5}$

$=0.176_{3} \pm 0.002_{2}$

The propagated standard deviation value of $0.002 ?$ rorresponds to a relative error of $1.23 \%$.

The capsule was irradiated in the MTR in a location near the beryllium reflector where the cadmium ratio for cobalt is 15. The Wescott "r" value corresponding to $\mathrm{R} \mathscr{C g}=15 \pm 3$ is $0.031 \pm 0.006$ computed from the relationship (3):

$$
r=\frac{g_{\mathrm{C}_{0}}}{{ }_{\mathrm{Cd}}^{\mathrm{Co}}\left[\mathrm{s}_{\mathrm{Co}}+\frac{1}{k} \sqrt{\frac{\mathrm{T}}{\mathrm{T}_{0}}}\right]-\mathrm{s}_{\mathrm{CO}}}
$$


in which:

$\begin{array}{lll}\mathrm{B}_{\mathrm{Co}} & = & 1 \\ { }_{\mathrm{Cd}}^{\mathrm{Co}} & = & \text { cadmium ration for cobalt }=15 \pm 3 \\ { }_{\mathrm{Co}}^{\mathrm{s}} & = & 1.795(\text { ref. } 4) \\ \mathrm{K} & = & 2.2931(\text { for } 0.040 \mathrm{in} . \text { of } \mathrm{Cd})(\text { ref. } 4) \\ \mathrm{T} & = & 313^{\circ} \mathrm{K} \\ \mathrm{T}_{\mathrm{O}}, & = & 293.6^{\circ} \mathrm{K}\end{array}$

to convert $\hat{\alpha}$ to $\alpha_{0}$, the $2200 \mathrm{~m} / \mathrm{sec}$ value, the relationship:

$$
1+\alpha_{0}=(I+\hat{\alpha})\left(g_{f}+r s_{f}\right) /\left(g_{a}+r s\right)
$$

applies. For a neutron temperature of $40^{\circ} \mathrm{C}\left(313^{\circ} \mathrm{K}\right)$ the values are:

$\begin{array}{lll}g_{f} & = & 0.9735 \pm 0.0016(\text { ref. 5) } \\ s_{f} & = & -0.0316(\text { ref. 5) } \\ r & 0.031 \pm 0.006 \\ \mathrm{~g}_{\mathrm{a}} & = & 0.9723 \pm 0.0012(\text { ref. 5) } \\ \mathrm{s}_{\mathrm{a}} & = & 0.1501(\text { ref. } 5) \\ \hat{\alpha} & = & 0.176_{3} \pm 0.002_{2} .\end{array}$

Therefore:

$\alpha_{0}$ for $U-235=0.171_{0} \pm 0.003_{4}(1.98 \%)$

The quoted error (standard deviation) 0.0034 includes errors in the measured $\widehat{\partial}$, epithermal parameter " $r$ ", and Westcott's quoted uncertainties for the $g$ values.

Krypton and Xenon Fission Yields. (R. M. Abernathey, L. L. Dickerson, R. E. Foster, Jr., F. L. Lisman, F. W. Spraktes)

These two gases were trapped from the capsule dissolver off-gas on molecular Sieve $5 \mathrm{~A}$ at $-190^{\circ} \mathrm{C}$. The concentration of each gas was determined hy temperature-programmed gas chromatography. The separated gas fractions from the chromatographic column were collected on charcoal at $-80^{\circ} \mathrm{C}$ and then transferred to the mass spectroscopy laboratory for isotopic distribution analysis. Details of the apparatus and the procedure for collection and analysis have been reported $(1,2)$. 
The analysis results and calculated absolute thermal fission yields are summarized in Table II for krypton and in Table III for xenon. The error associated with each value for the xenon isotopes is the standard deviation. Due to a power failure during recycling of the krypton, through the gas chromatograph, no error can be assigned to the volume of krypton obtained and hence to the various krypton fission yields. 
Table II. THERMAL FISSION YIELDS OF KRYPTON ISOTOPES FOR U-235

$$
\text { std cc } \mathrm{Kr}=0.0363
$$

Isotopic distri-

bution, atom \% 14.42

Determined

number of

atoms

Atoms after

correction

for neutron

capture and

radioactive

decay.

Percent fission

yield

0.529
$\mathrm{Kr}-83$

$1.4073 \times 10^{17}$

$\underline{\mathrm{Kr}-84}$

27.43

6.43

51.72

$\underline{\mathrm{Kr}-85(10.76 \mathrm{yr})} \mathrm{Kr}-86$
$2.6771 \times 10^{17}$

$6.2755 \times 10^{16}$

$5.0477 \times 10^{17}$

$1.4327 \times 10^{17}$

$2.6526 \times 10^{17}$

$7.6363 \times 10^{16}$

$5.0469 \times 10^{17}$

0.980

0.282

1.86 
Table III. THERMAL FISSION YIELDS OF XENON ISOTOPES FOR U-235

std $\operatorname{cc} \mathrm{Xe}=0.2552 \pm 0.0051(2.0 \%)$

$$
\underline{X e-131} \underline{X e-132} \quad \underline{X e-134} \quad \underline{X e-136^{a}}
$$

Isotopic distri-
bution, atom \% 10.66
16.01
29.09
44.25

Determined num-

ber of atoms

$7 \cdot 3141 \times 10^{17}$

$1.0985 \times 10^{18}$

$1.9959 \times 10^{18}$

$3.0361 \times 10^{18}$

Std Dev

0.1463

0.0220

0.0399

0.0607

\begin{abstract}
Atom "after cor-
rection for

neutron capture

$7.3624 \times 10^{17}$

$1.0935 \times 10^{18}$

$1.9867 \times 10^{.18}$

Sta Dev, .\%

(includes esti-

mated uncer-

tainties in

correction

factors for

neutron capture) 2.0

$2.0 \quad 2.0$

Percent fission

yield

2.72

4.04

7.34

Std Dev

0.06

0.09

0.17

Std Dev, \%

2.3

2.3

2.3

a) No attempt was made to distinguish those atoms of $\mathrm{Xe}-136$ resulting from $\mathrm{Xe}-135(\mathrm{n}, \%) \mathrm{Xe}-136$ reactions and hence no Xe-136 fission yield can be reported.
\end{abstract}


$\mathrm{Rb}-85$ and $\mathrm{Rb}-87$ Fission Yields. (R. M. Abernathey, R. E. Foster, Jr., M. E. Kussy, F. L. Lisman, R. E. McAtee, R. A. Nielson, F. W. Spraktes, G. D. Workman)

The absolute thermal fission yields of $\mathrm{Rb}-85$ and $\mathrm{Rb}-87$ were determined by isotope dilution mass spectrometry. Eight aliquots, four spiked with a known amount of $\mathrm{Rb}-85$ and four without spike, of the dissolver solution were chemically separated and then analyzed by massspectrometry. The chemical separation and mass spectrometric procedures have been previously reported (6).

The analysis results and calculated absolute thermal fission yields are summarized in Table IV. The method of calculation and the error propagation for the determined number of $\mathrm{Rb}-85$ and $\mathrm{Rb}-87$ atoms have been previously reported (6).

To calculate the yield of the 85 mass chain, the number of determined $\mathrm{Rb}-85$ atoms was added to the determined atoms of $10.76-\mathrm{yr} \mathrm{Kr}-85$.

The accurate determination of absolute fission yields, for samples which have undergone long term irradiations, requires corrections for the buildup and burnout of the various fission products due to neutron capture. The method of correcting for buildup and burnout of the fission products is based on a series of computer programs which simulate the irradiation history of the sample. These programs yield the number of individual fission product atoms formed during the irradiation and their manner of formation. In addition, the programs consider the decay of any radioactive nuclides. for the time period between termination of the irradiation and sample analysis. Details of these programs have been previously reported $(6,7)$. 
Table IV. THERMAL FISSION YIELDS OF Rb-85

AND Rb-87 FOR U-235

\begin{tabular}{|c|c|c|}
\hline & $\underline{\mathrm{Rb}-85}$ & $\underline{\mathrm{Rb}-87}$ \\
\hline Determined number of atoms & $2.8862 \times 10^{17}$ & $6.8075 \times 10^{17}$ \\
\hline Std Dev avg $(n=4)$ & $0.0219 \times 10^{17}$ & $0.0372 \times 10^{17}$ \\
\hline $\begin{array}{l}\text { Atom after correction } \\
\text { for neutron capture }\end{array}$ & $2.8869 \times 10^{17}$ & $6.8075 \times 10^{17}$ \\
\hline $\begin{array}{l}\text { Std Dev, \% (includes } \\
\text { estimated uncertainties } \\
\text { in correction factors } \\
\text { for neutron capture). }\end{array}$ & $0.76 \%$ & $0.55 \%$ \\
\hline $\begin{array}{l}\text { Determined atoms of } \\
10.76-\mathrm{yr} \mathrm{Kr}-85^{\mathrm{a}, \mathrm{b}}\end{array}$ & \multicolumn{2}{|c|}{$(0.6275 \pm 0.0188) \times 10^{17}$} \\
\hline rotal mass - 85 at & \multicolumn{2}{|c|}{$(3.5144 \pm 0.0289) \times 10^{1 \%}$} \\
\hline
\end{tabular}

Percent fission yield

1.30

2.52

Std. Dev

0.02

0.03

Std Dev, \%

1.5

1.2

(a) Not corrected for either out-of-pile or in-pile decay. The sum of the determined $\mathrm{Kr}-85$ and the determined $\mathrm{Rb}-85$ is the total number of mass -85 atoms because the krypton is quantitatively removed from the dissolver solution at time of dissolution.

(b) The relative standard deviation on the determined number of $10.76-\mathrm{yr}$ $\mathrm{Kr}-85$ atoms is estimated to be $\pm 3.0 \%$. 
Ruthenium Fission Yields (R. M. Abernathey, R. E. Foster, Jr., M. E. Kussy, F. L. Lisman, R. E. McAtee, R. A. Nielson, F. W. Spraktes, G. D. Workman)

The absolute thermal fission yields of four ruthenium isotopes, Ru-101, -102, -104 , and -106 , were determined by isotope dilution mass spectrometry. The atoms of Ru-106 also were measured radiometrically. Four 1000- $\mu 1$ aliquots from the dissolver solution were spiked with known amounts of $\mathrm{Ru}-106$ and carried through the separation and analysis procedure. The detailed separation and analysis procedures have been previously described (8). The analysis results and the calculated fission yields are summarized in Table $\mathrm{V}$.

As in the case of the thermal fission yields of rubidium, corrections for the buildup and burnout of the ruthenium isotopes are based on a computer program which simulates the irradiation history of the capsul.e.

Comparison to Previous Results

A comparison of the absolute thermal fission yields determined on the present capsule to previously determined values for other U-235 capsules is given in Table VI. The agreement between the various capsules is well within experimental error. 
Table V. TEERMAL FISSION YIELDS CF LONG-IIVED AND STABLE RUTHENIUM ISOTOPES FOR U-235

Determined number of atoms

Std Dev $_{\text {avg }}(n=4)$

F Atoms after correction for neutron capture and decay

Std Dev (\%)

Percent Fission Yield

Std Dev

\begin{tabular}{|c|c|c|c|c|}
\hline Ru-ICI & $\mathrm{Ru}-102$ & Ru-104 & $\underline{\mathrm{Ru}-106}$ & $\begin{array}{l}\text { Ru-106 } \\
\text { (Radiometric) }\end{array}$ \\
\hline $1.3658 \times 10^{1 \varepsilon}$ & $1.1400 \times 10^{18}$ & $4.9938 \times 10^{17}$ & $1.3140 \times 10^{1}$ & $1.3587 \times 10^{1.6}$ \\
\hline $0.0080 \times 10^{13}$ & $0.0072 \times 10^{18}$ & $0.0316 \times 10^{17}$ & $0.0214 \times 10^{1}$ & $0.0434 \times 10^{16}$ \\
\hline . & . & & & \\
\hline $1.3662 \times 10^{18}$ & $1.1400 \times 10^{18}$ & $4.9927 \times 10^{17}$ & $1.1218 \times 10$ & $1.093 \times 10^{17}$ \\
\hline 0.59 & 0.63 & 0.63 & 1.9 & 3.4 \\
\hline 5.05 & 4.21 & 1.84 & 0.414 & 0.404 \\
\hline 0.07 & 0.06 & 0.02 & 0.010 & 0.015 \\
\hline
\end{tabular}




\begin{tabular}{|c|c|c|c|}
\hline Isotope & This Capsule & $\frac{6-4-1}{(\operatorname{Bef} .2,6,8)}$ & $\frac{6-6-2}{(\operatorname{Re} f \cdot 7,6,8)}$ \\
\hline $\mathrm{K} r-83$ & 0.529 & $0.491 \pm 0.020$ & $0.499 \pm 0.010$ \\
\hline $\mathrm{Kr}-84$ & 0.980 & $0.919 \pm 0.027$ & $0.936 \pm 0.019$ \\
\hline $\mathrm{Rb}-85$ & $1.30 \pm 0.02$ & $1.30 \pm 0.02$ & $I .31+0.02$ \\
\hline $\mathrm{K} r-86$ & 1.86 & $1.79 \pm 0.06$ & $1.82 \pm 0.04$ \\
\hline $\mathrm{Rb}-87$ & $2.52 \pm 0.03$ & $2.57 \pm 0.03$ & $2.58+0.04$ \\
\hline $\mathrm{Ru}-101$ & $5.05 \pm 0.07$ & $5.03 \pm 0.06$ & $5.02 \pm 0.07$ \\
\hline $\begin{array}{c}1 \\
\mathrm{Ru}-102\end{array}$ & $4.21 \pm 0.06$ & $4.18 \pm 0.08$ & $4.17 \pm 0.06$ \\
\hline $\mathrm{Ru}-104$ & $1.84 \pm 0.02$ & $1.81 \pm 0.02$ & $1.81 \pm 0.03$ \\
\hline $\mathrm{Ru}-106$ & $0.414 \pm 0.010$ & $0.373 \pm 0.006$ & $0.398 \pm 0.008$ \\
\hline Ru-106 (radiometric) & $0.404 \pm 0.015$ & $0.382 \pm 0.013$ & $0.412 \pm 0.015$ \\
\hline $\mathrm{Xe}-131$ & $2.72 \pm 0.06$ & $2.78 \pm 0.09$ & $2.87^{ \pm 0} 0.06$ \\
\hline $\mathrm{Xe}-132$ & $4.04 \pm 0.09$ & $4: 15 \pm 0.14$ & $4.28 \pm 0.09$ \\
\hline $\mathrm{Xe}-134$ & $7.34 \pm 0.17$ & $7.53 \pm 0.25$ & $7.73^{ \pm 0} 0.20$ \\
\hline
\end{tabular}




\section{REFERENCES}

I). Maeck, W. J., Rein, J. E., Editors, Burnup Determination of Nuclear Fuels: 1964 Annual Report, IDO-14656 (1965).

2). Maeck, W. J., Rein, J. E., Editors, Burnup Determination of Nuclear Fuels: Project Report for the Quarter January 1-March 31, 1965, IDO-14660 ( 1965$)$.

3). Westcott, C. H., Effective Cross Section Values for Well Moderated Thermal Reactor Spectra, CRRP-960 (AECL-1101) (1960).

4). Westcott, C. H., Walker, W. H., Alexander, T. K., Effective Cross Sections and Cadmium Ratios for the Neutron Spectra of Thermal Reactors, A/Conf. 15/p/202 (1958).

5). Critoph, E., Effective Cross Sections for U-235 and Pu-239, CRRP-I19I (CRRP-960 Addendum) (1964).

6). Lisman, F. L., Maeck, W. J., and Rein, J. E., Editors, Burnup Determination of Nuclear Fuels: Project Report for the Quarter January 1-March 31, 1967 , IN-1157 Rev. (1968).

7). Maeck, W. J., Rein, J. E., Editors, Burnup Determination of Nuclear Fuels: Project Report for the Quarter July I-September 30, 1965, IDO=14667 (1965).

8). Maeck, W. J., Abernathey, R. M., Rein, J. E., Editors, Burnup Determination of Nuclear Fuels: Project Report for the Quarter October 1-December 31, 1965, ID0-14676 (1966). 